\title{
Family Evaluation of Hospitalized Elderly with Encephalic Vascular Accident under Palliative Care

Marcella Costa Souto Duarte ${ }^{1}$, Solange Fátima Geraldo da Costa², Karla Fernandes de Albuquerque ${ }^{1}$, Maria Eliane Moreira Freire ${ }^{3}$, Patrícia Serpa de Souza Batista ${ }^{4}$, Maria Emília Limeira Lopes ${ }^{2}$, Betânia da Mata Ribeiro Gomes5, Marta Miriam Lopes Costa ${ }^{2}$

\section{Abstract}

Objective: evaluate the structure, the development and the functionality in families of hospitalized elderly patients with vascular encephalic accident under palliative care.

Method: qualitative field research conducted with five families. Data were collected through the technique of interview, genogram and ecomap. The empirical material was analyzed in light of the Calgary Family Assessment Model.

Results: it was verified that the participant families of the study retained the nuclear structure; presented low and education levels and financial difficulties. However, two families showed better economic conditions. As for the social support network, majority mentioned relatives, friends and the church. All referred to have conflictual family relationships. The family caregivers are females, specially daughtersin-law and daughters.

Conclusions: The structural, developmental and functional evaluation of the families in the study provide a space for nursing intervention in the hospital context for the families of hospitalized elderly with cerebral vascular accident.

\section{Introduction}

In the contemporary world, oncological and cardiovascular diseases and multiples degenerative processes contribute to the aggravation of health framework, as a result of the progressive aging of the world population [1]. With the advent of an aging population, also emerged
1 Nurse. PhD. Teacher of the Nursing Course of the João Pessoa University Center, Paraíba, Brazil.

2 Nurse. PhD. Teacher post graduation of Federal University of Paraíba, João Pessoa, Paraíba, Brazil.

3 Nurse. PhD. Teacher graduation Federal University of Paraíba, João Pessoa, Paraíba, Brazil.

4 Nurse. PhD. Teacher post graduation of Federal University of Pessoa, Paraíba, Brazil.

5 Nurse. PhD. Teacher post graduation University of Pernambuco, João Pessoa, Paraíba, Brazil.

Contact information:

Marcella Costa Souto Duarte.

”m marcellasouto@hotmail.com

Keywords

Family Relationships; Elderly; Palliative Care. 
other not transmissible chronicle diseases, such as cerebral vascular accident (CVA), which is currently considered the third most common causes of death in developing countries [2]. In addition to high mortality, this pathology is also responsible for causing physical, psychological, cognitive and social deficits in affected individuals, causing high rates of disabilities, particularly in the elderly [3].

Functional disability may cause difficulties for the elderly to perform daily activities, which can be temporary or permanent, depending on the affected area. Therefore, these difficulties might compromise quality of life of the elderly and interfere in their family [4]. In case of permanent brain damage, implying in a stage of disease in which there is no possibility of cure, it is necessary the indication of palliative care in order to improve their and their relatives' life.

Palliative care are defined by the World Health Organization [5] as active and total care of patients whose disease no longer respond to curative treatment. It is a differentiated care approach, which promotes improvement in quality of life of patients and their relatives through the evaluation of adequate treatments for pain and symptoms management and provides psychosocial and spiritual support. It is required integrated actions of a multidisciplinary team because, in this mode, care must be individual and involve physical, mental, spiritual and social aspects [6]. For the implementation of such cares, the participation of nurses deserves importance, due to the time that they remain with patients and their families, mediating the interaction among those involved in the care process with features that improve the quality of life and, when this is not possible, provide a dignified death [7].

Therefore, while assisting patients with CVA under palliative care and their relatives, nurses should guide their care practice through theoretical framework within Nursing, such as the Calgary Family Assessment Model (CFAM), which is a multidimensional structure composed of three categories: structural category, covering the internal and external structure of family; category of development or developmental category, which involves stages, tasks and links; functional category, which includes activities related to daily life. The CFAM uses two tools to describe the internal and external structure of families: the genogram and ecomap [8].

The genogram is a family group diagram that describes the structure and family history, health conditions of each individual and the quality of relationships among its members. The ecomap represents an overview of the family, portrays important educational or conflictual relationship between the family and the world, that is, represents family members relationships with larger systems [8].

Researchers $[9,10]$ clarify the importance of evaluating the structure, development and functionality of families through the CFAM. Nevertheless, in the Brazilian scenario, there is an incipient quantitative of studies related to families with hospitalized elderly with CVA under palliative care grounded by this model. Hence, researches on CFAM contribute greatly to subsidize assistance from nurses to elderly patients with CVA under palliative care and their families in a hospital setting.

In this way, it was considered appropriate to develop a study with guiding question: how is the structure, development and functionality of families with elderly patients with CVA under palliative care? To respond it, the objective of the study was determined to evaluate the structure, development and functionality of families with elderly patients under palliative care.

\section{Method}

\section{Theoretical-methodological framework and type of study}

This is a qualitative field research based on the Calgary Family Assessment Model. The study scenario was a philanthropic hospital located in João Pessoa, 
the state capital of Paraíba, which is a reference in healthcare structure to attend patients in terminal state and with incurable diseases.

\section{Data Sources}

The population of this research consists of elderly patients and family caregivers hospitalized in the period that data were collected in the selected institution for the proposed study. In the sample selection process, it was considered the following inclusion criteria: patients over sixty years old with a CVA diagnostic which scored equal or less than $50 \%$ in the Palliative Performance scale, that were conscious and lucid in the period of data collection and receiving palliative care. Such scale [11] is a valid tool used to verify eligible situation in relation to patients under palliative care, since it enables the evaluation of the functionality and comprehension of the disease history.

As for the family member selection, the following criteria were adopted: the family member should be at least eighteen years old and be accompanying the elderly patient during data collection. Based on these criteria, the study sample consisted of five families represented by five elderly patients with CVA who were being treated in the palliative care perspective and five accompanying relative totaling ten participants. It should be noted that the amount of participants was considered satisfactory, since in qualitative researches the number of individuals is not prioritized, but the investigated phenomenon [12].

\section{Collection and organization of data}

The data was collected from August to September of 2014. To render viable the collection with the families, it was used two tools recommended by the Calgary Family Assessment Model (CFAM) [8] - genogram and ecomap - and interviews based on a previously structure script containing relevant questions to the scope of the study. The genograms and ecomaps of the participant families were deve- loped by data reported by patients and caregivers. The interviews were recorded by recording systems from MP4 players and by the field diary to record annotations of the Palliative Performance Scale from elderly patients.

\section{Data Analysis}

The empirical data obtained from the reports of elderly patients and their caregivers in the study were qualitatively analyzed in light of CFAM through the categories proposed by the model, namely: structural, developmental and functional.

\section{Ethical Aspects}

It is notable that the investigation met ethical observances related to researches that involve human subjects, recommended by the Resolution 466/2012 13 of the National Hearth Council, the project was approved by the Ethics Committee of Research of the Federal University of Paraíba, under CAAE of number 33261114.1.0000.5183. It was attributed biblical names to the patients participating in the study and fictitious names to their relatives conserving the first letter of their real name to preserve their identities.

\section{Results}

The investigated families presented as index cases three women and two men with CVA under palliative care. The structure of the families that composed the research is illustred by genograms and ecomaps in the Figures 1, 2, 3, 4 and $\mathbf{5 .}$

\section{Ana's Family}

The Figure 1 shows Ana's family structure, 70 years old, retired, illiterate, widowed and residing in João Pessoa - PB. Ana had four children, one dead and three living daughters: Rejane, Rosimeire and Rosa. This last one is a homemaker, married with Sergio, military. They have two daughters: Daniele, married with Carlos; and Elisa, single and college student. 
Figure 1: Graphical representation of the genogram and ecomap of Ana's Family, João Pessoa, 2014.
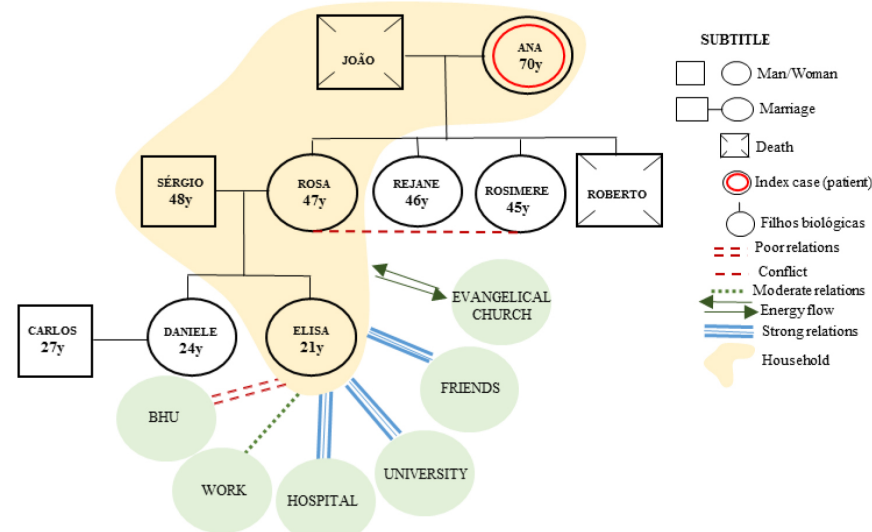

Source: Empirical study material, João Pessoa - PB, 2014

The results showed that there is a conflicting relationship among Ana's daughters, since the youngest daughter Rosimeire seems to be more absent in caring about the health of her mother. Rosa reported that their family relationship with the Family Basic Unit [UBS] is weak, so when some of the family members need health care they seek the Military Hospital. The family nucleus has a strong relationship with friends. According to Rosa, her husband is a minister, the family group is evangelical, everybody attend the Church and the religion means nothing if you do not have an encounter with God, because what matters is faith in him. Rose commented that is partially responsible for taking care of her mother Ana and shares this responsibility with her sister Rejane.

\section{Rebeca's Family}

The Figure 2 shows Rebeca's family structure, a 93 years old woman, who complete elementary school, retired, widow, mother of ten children. She lives in the countryside of the state with Carlos, her daughter-in-law Manuela and her three grandchildren: Antônio, Ângelo and Angélica. Carlos is 68 years old, retired and married with Manuela. They have three unmarried children: Antônio, 27, store clerk; Ângelo, 26, motocycle courier; and Angélica,

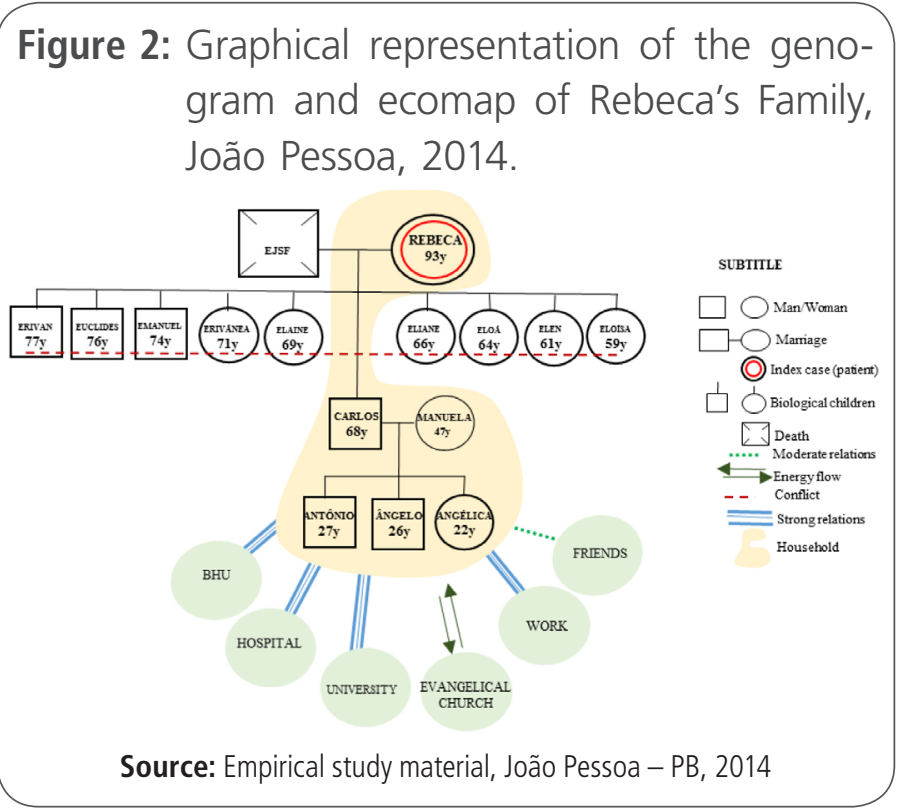

22, college student. The figure 2 reveals also that there is a conflicting relationship among all Rebeca's children. Her daughter in law Manuela commented about this relationship of conflict:

My mother-in-law lived in six houses from her children, but it did not worked out, she lived abandoned there [...]. Then my husband Carlos went to court and she came to live with us [...] it has caused lots of trouble, and my sister-in-law denounced us and the public prosecutor went to my house. Everything that I do I communicate to the Public Prosecution.

The relationship of the family with the county hospital and the Health Basic Unit is strong. The family nucleus has a moderate relationship with friends. According to Manuela, the family is Evangelic.

The patient Rebeca is under the care of her daughter-in-law Manuela who stated: I have enormous pleasure in taking care of my mother-in-law! Regarding visitations, Manuela said: She receive few visitors! Today came one of her daughters who hasn't seen her for six years.

\section{Madalena's Family}

Figure 3 describes Madalena's Family, a 93 years old woman, retired, illiterate and widowed, who had three children - two dead and one alive. Living 
in the capital of the State with her son Severino and her daughter-in-law Maria de Lourdes who is 47 years old and homemaker. Her granddaughters are Flávia, 27 years old, homemaker and Flávia, 26 years old, shopkeeper. Her great-grandchildren are

Figure 3: Graphical representation of the genogram and ecomap of Madalena's Family, João Pessoa, 2014.

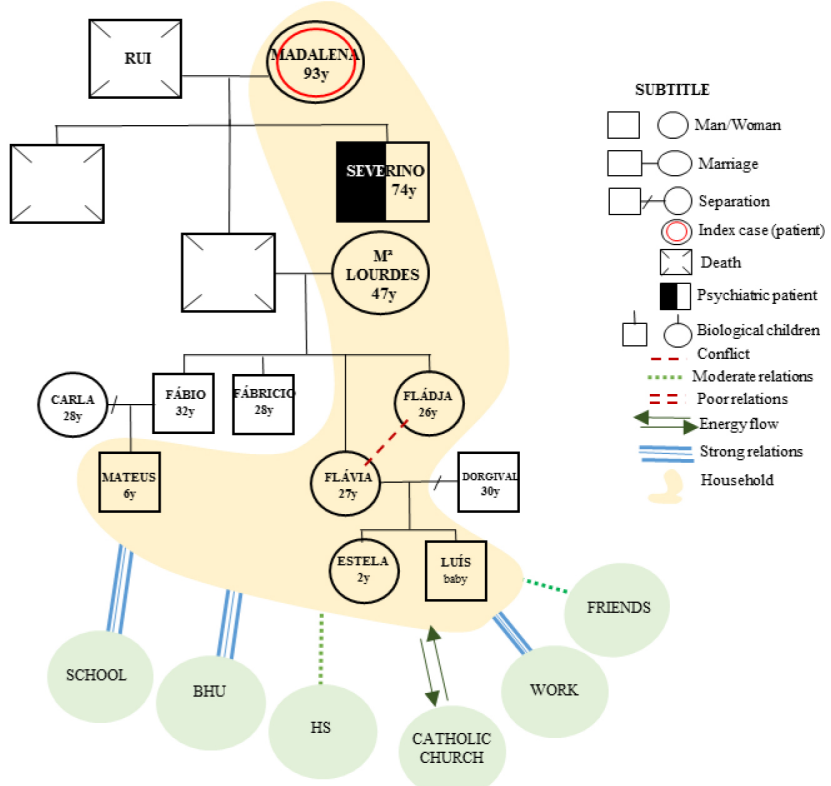

Source: Empirical study material, João Pessoa - PB, 2014

Figure 4: Graphical representation of the genogram and ecomap of André's Family, João Pessoa, 2014.

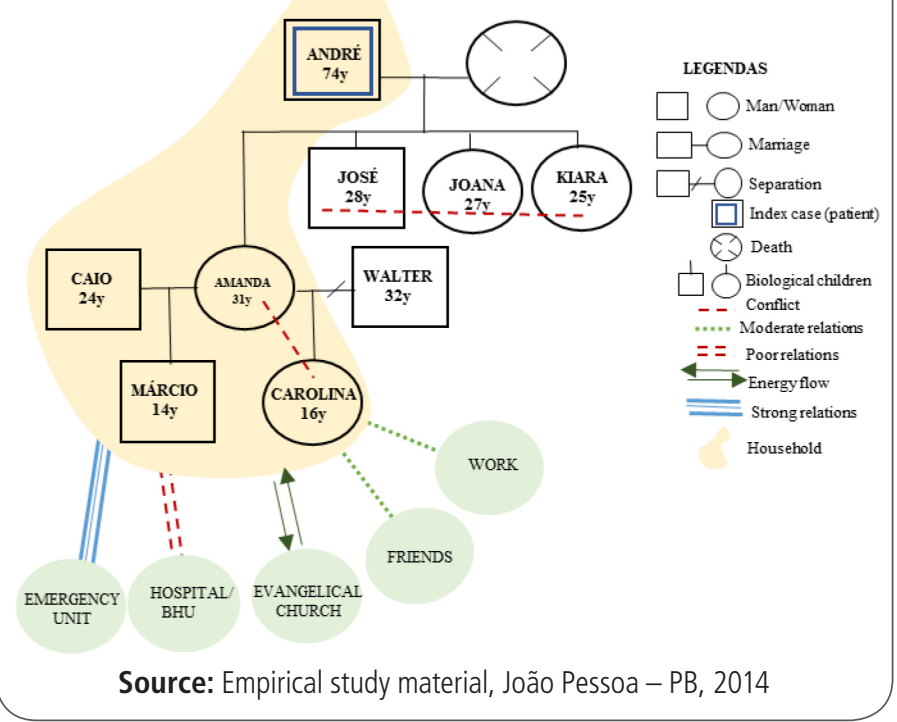

Mateus, 6 years old, Estela, 2 years old and Luís, two months old.

When the family members need health services, they seek the Health Basic Unit and Home Care Services in which keep strong relationships. The family nucleus maintain also a strong relationship with school and work and moderate with friends. According to Maria de Lourdes, patient's daughter-in-law, majority of the family follow Catholicism. According to her testimony, the family has a good intimacy: Thank God, we live in very good conditions [...] Madalena said she has few visits. She comments I have a friend who is like a sister, but she is also sick and cannot visit me!

\section{André's Family}

Figure 4 represents the structure of André's Family, a 74 years old man, retired and pensioner, illiterate and widowed. He has four children and lives with his daughter Amanda who is 31 years old, homemaker, separated from Walter, 32, and married with Caio, 24 years old and commerce worker. She also lives with her granddaughter Carolina, 16, from Amanda's first marriage, and her grandson Márcio, 14, from Amanda's second marriage.

Amanda comments that the family relationship with the Emergency Care Unit is strong, however, their relationship with the Basic Health Unit and the hospital is weak, since there is a poor quality service and it is not provided resolutivity to the family. The family nucleus has moderate relationships with friends. The family is evangelical, however, Amanda says: [...] after this disease, my father stopped attending the church.

Amanda affirms that the family has a good family environment, but she and her daughter Carolina sometimes come into conflict as reported: [...] my daughter is too unruly [...] she lived with me but just wanted to stay on the streets and did not want to go to school [...]. Then I picked her up and sent to her father's house [...] then she is now living with me and with her father. 
The care with patient André is responsibility of Amanda and her sister Kiara.

Amanda asserts that her farther is almost not visited by the family. Furthermore, she commented $[. .$.$] there is only me and my younger sister [...] the$ rest of the siblings say that they cannot come [...] we called them to come here to help us, but they create difficulties [...]

\section{João's Family}

Figure 5 illustrates João's Family, a 76 years old man, retired with incomplete primary school and married with Francisca, 64, retired and with incomplete primary school. The couple has five children and lives with their son Argemiro, 46, theacher; their daughter-in-law Gilda, 38, homemaker; and their grandsons Jaelson, 17, and Jacó, 11, both are students.

Gilda asserts that the relationship of the family with the Basic Health Unit and with the Emergency Care Unit is strong and that the family is catholic. As for hospital visits she affirms: his children always come to visit him whenever they can [...]. She asserts also that everyone has good relationships except for two daughters, Valéria and Luísa. She reports: [...] one wants to leave him at home, the other think that is better he stay at the hospital.

Figure 5: Graphical representation of the genogram and ecomap of João's Family, João Pessoa, 2014.

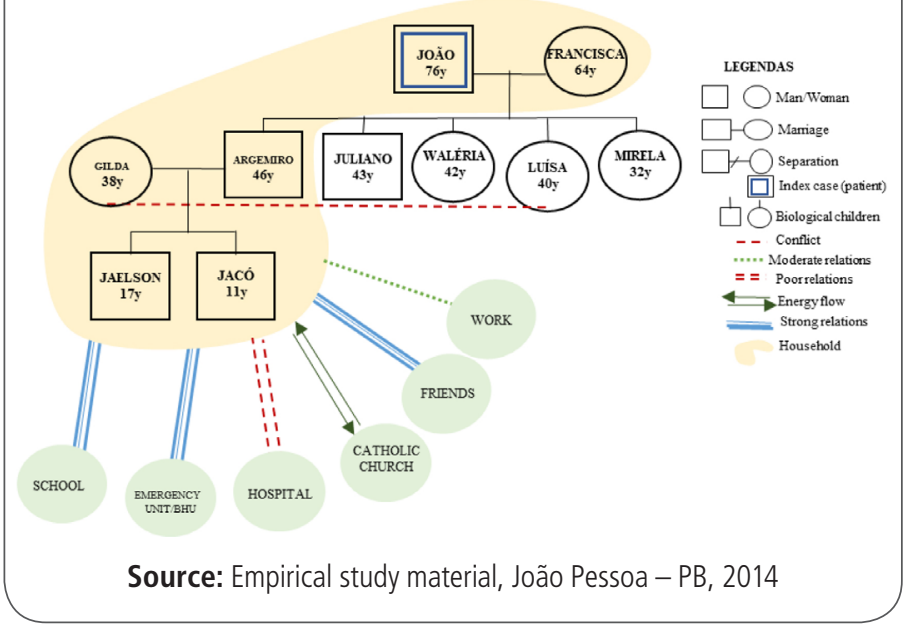

The responsibility of caring for patient João is shared among daughters and daughters-in-law.

The Calgary Model, as an integrated framework to assess families, provides an expanded view of the family system, which includes its internal and external structural relations and its development on a sickening situation of one of its members. In this study, it is emphasized the elderly.

\section{Discussion}

\section{Structural Evaluation}

Aiming to conduct a family assessment it is necessary to considerate its structure - composition, emotional ties and context [8].

As for the internal structure, it was verified that the five participant families preserved their nuclear structure, that is, the elderly couple, children and grandchildren composed them. Regarding the external structure, it was observed that all the families were supported by diverse elements from social networks, such as churches and friends. However, it was noted that Ana's, André's and João's families showed weak relationships of their members with larger systems - health services.

Concerning the context category of the structural evaluation, especially in relation to the social class subcategory, the study showed that Rebeca's, Madalena's and André's family received a low income. Their monthly income was in average two minimum wages. These data is similar to those found in population-based studies with elderly [14]. It is important to note that Ana's and João's families possessed better financial conditions from four to five minimum wages.

As for education, it is predominant uneducated people or with few years of school, particularly, the elderly. These results confirm national statistics [15], by indicating that in our country the elderly have lower educational levels. This is due to the difficulties of access to school and the lack of apprecia- 
tion of formal education in the last century, when boys should work and girls should take care of the house and younger siblings. On this aspect, low educational levels should be considered by health professionals in implementing activities focused on the elderly, which contribute to gain knowledge about the aging process and enable to live more healthfully in this period of life [16].

Another aspect evidenced by this study related to the description of the external structure of the families from the sample was the family network of relationships, which can be understood as a family network support and broader systems. In attending the specific needs of the elderly, social support systems are essential and classified as formal [hospitals and home care] and informal (family, friend and work) [17]. By observing the external structural, it was verified a predominance of moderate family relationships, strong with friends and weak and moderate with hospitals and Health Basic Units (UBS).

By comparison, the results of this research with the cross sectional study [18], conducted with a random sample of 220 elderly in the state of Rio Grande do Sul, as for the formal support, it was found that the elderly in that study also reported receiving little support. Thus, the creation of structures of formal support networks is a major challenge for many Brazilian cities that have already been facing the aging of the population [18].

In what concerns the flow of energy to the Church, in this study it was evidenced strong relationships of families with religious institutions. Authors [19] clarify that religious centers are important to create networks and practices of social support that help in confronting health problems and diseases. Therefore, the religious involvement associates with better mental health, which generate positive impact on quality of life [20].

\section{Developmental Evaluation}

This category deals with the stages of life cycle of each family, their tasks and connections [8].
Regarding the health history, Rosa, Ana's daughter, reported that her mother detected implications of CVA one year ago. She described the initial difficulty to deal with this reality of hospitalizations, as expressed in this talk:

[..] After my mother had a stroke [...] then we started to have notion that her situation was worsening [...] now that she stopped working she depends on us for everything.

Rosa.

Rebeca showed implications of CVA only two months ago. About this, her daughter-in-law comments:

[...] it was hard to to get the news about this disease because my husband is also old and was very shaken because of his mother situation.

Manuela.

Madalena showed diagnosis of CVA a month ago and streptococcus that has existed for two weeks. Her daughter-in-law reports:

[...] I cried, I became desperate [...]. To say flat out that the person that you like has a disease is sad! [...] the doctor said that her injury was too big [...] it was the toughest conversation of my life!

Maria de Lourdes.

As for André, he was diagnosed with CVA around one year ago and depends on the Unified Health System [SUS]. Amanda, his daughter, comments about her father's health:

[...] He doesn't walk anymore, I take him to the toilet and he walks shaking a lot. Today he stopped talking. It is very difficult. Every day is more difficult. There is a lot of stress to care take of him. Get him up... I get back pain... it is not very good.

Amanda. 
João was diagnosed with CVA in October 2014. About his health, his daughter-in-law Gina, expressed herself:

[...] after the CVA [...] I know that he is really bad [...] it is going to be really hard to live without him I am going to miss him (crying) [...] everybody is sad [...] the affliction is going to be huge! [...] one of his daughters is not going to accept.

In this evaluation, it was found that the families experienced difficulties to deal with hospital admissions of their elderly relatives and with proximity to death, expressing anxiety and fear. Thus, authors [20] agree that some subjective aspects should be assessed, such as: adapt to new realities in stressful situations, share decision and responsibilities, interact emotionally in the family context and have shared time.

Studies [21] have proposed that, historically, health problems in elderly are correlated with the precariousness of the current public health model in the country. In contrast, results of international studies [22] developed in England with 80 patients with sequelae of stroke and 34 family caregivers showed that health services that provided care to these patients offered support to physical and emotional needs, social activities and leisure.

In this way, families are able to face difficult situations, experience the care of family members in the hospital context and deal with the finitude of life.

Regarding the development stages of family life, in this study, only Madalena's family lived with kids; two families with adolescents [André's and João's families]; and two with adults. Results of a quantitative cross-sectional study [23] developed in families with elderly residing in peripheral suburbs of Fortaleza (CE) show that the presence of kids and adolescents establishes important intergenerational relationships: between grandparents and grandchildren in direct living under family area. These are arrangements that usually provide feelings of protection and care.

Researchers [24] assert that the evolution in family intergenerational demography has provided elderly conviviality to a higher number of generations with a lower number of members. Such conviviality constitute a space of changes in the family context structure, with contributions and attributions linked to different stakeholders. It is noted that cohabitation is a strategy that produce benefits to elderly and their descendants, despite some families are not able to provide necessary support to dependent elderlies [25].

On the other hand, more contact and demand of family care for the elderly may initiate conflicts and dissatisfaction, which can lead to changes in intrafamily roles and choice of the main caregiver [26]. Moreover, in cohabitation, there is also a greater risk of mistreatment and negligence, especially if this occurs in a context of material resources scarcity and conflicts of interest [25].

As for the tasks subcategory, it was found in Madalena's family, which lived with small young children, changes in family processes, mainly in the relationship with kids, adding it up to the stressor agent, which is the illness of a family member. In addition, it was observed the division of housework and care of the elderly affected by CVA, as shown in the following report:

[...] when I am at home, I share with my daughter the things to do [...] I bathe my mother-in-law, adjust her bandage [...] when I am here at the hospital who does everything is my daughter Flávia. She bathes the boys, takes them to school, cooks the lunch, puts the dirty clothes in the washing machine, cleans the house, does everything!

Maria de Lourdes.

This speech shows the dedication of the daughter-in-law, who accumulates the caregiver 
function of her mother-in-law affected by CVA. To perform this function in the hospital, she leaves the burden of domestic tasks only with her daughter. This is a common situation, when it is experienced the illness of a family member. However, it is important that there are, whenever possible, division of tasks, both in the hospital and at home, to minimize the stressors that this situation causes to the family.

Regarding the bonds, it should be noted that the accommodation of the daughters-in-law, directed to the elderly with stroke sequelae, was observed in three families (Rebeca's, Madalena's and João's) and the daughters [Ana's and André's], was implemented by gender issues, since the patients see women as main caregivers. With regard to family assessment bonds, it was noted in this study that family caregivers, elected by the elderlies and other family member, are females.

Authors [Machado; Jorge; Freitas, 2009] proposed that, in general, majority of the caregivers live with the elderly and, consequently accumulate activities related to care - mother, wife and grandmother - that leads to caregiver burden. In this context, it is observed that, despite all social changes and changes in the composition of families and in the new roles occupied by women, such as their greater participation in the work market, it is yet expected that women occupy caregiver positions [27].

\section{Functional Evaluation}

The functional evaluation involves the details of how the individuals generally behave among themselves, by aggregating two dimensions about family functioning, which are, the instrumental and the expressive [8]. By the instrumental evaluation, it was established that the financial issue was considered a relevant factor (families of André and Rebeca), since it appeared to be relevant for the quality of care given to elderly with CVA, as shown in these reports:
[...] If the conditions were better, we could give more assistance to her [...] because we always keep running from a place to another looking for a place for her to be admitted and that is too bad.

Manuela.

[...] If I had more money, we wouldn't wait so long for him to be admitted

Amanda

The five family relatives of elderlies with CVA, who participated of this research, were females and were their main caregivers. This helped to identify the exhaustion of two of the family caregivers in the expressive functionality, which can be noted in the reports below:

[...] Before I used to do cleaning jobs, to sew clothes, to sell my stuff, I was more outside than inside my house. [...] I had to leave everything to take care of her. I think: gosh, she has so many children, so many grandchildren but none of them helps. [...]

Manuela.

[...] When I am here at the hospital my house becomes messy. I am just going home in weekends, when my sister gives me a day off. I stay away from my son and my husband. [...]

Amanda.

These reports state that caring for hospitilized elderly with CVA using knowledge about palliative care demands total dedication of the caregivers that are forced to cancel their household chores and their own social experiences in detriment of the care activity. These reports also show that few family members become available to provide care to their relatives in disease situation. This leads to overburden ones in detriment of others, who cannot or do not want to assume these tasks in their lives or feel unable to care for a hospitalized patient. 
Regarding the expressive functioning of the funcional evaluation, this study found an elderly caregiver burden, which is in accordance with researches $[28,29]$. In this way, researchers [30] clarify that the caregiver and the family must be prepared using counselling for guilt, frustration, anger, sadness, depression and other feelings that follow the responsibility of caring for an infirm family member.

As for the care provided to the hospitalized elderly patient with CVA, under palliative care, the health professionals, especially the ones from Nursing, should seek strategies to provides a holistic and humanized assistance to the patients and their relatives, since this period experienced by them causes not only feelings related to diseases but also to disability and proximity of death. In the case of elderly patients with CVA who are receiving such care, Nursing should play its fundamental role, especially in situations of functional dependency.

\section{Conclusions}

The family evaluation supported by the Calgary Model, object of this study, enabled to perform a detailed analysis of the family structure, development and function of elderly individuals with CVA under palliative care surveying its main aspects.

It is known that the operationalization of nursing practises in the hospital setting is a unique moment for the provision of effective patient care, to offer emotional support, as well as to help families to face critical situations, such as aging with disease and dependence in order to minimize their suffering.

In this study, it was verified some difficulties experienced in the daily context, especially by Rebeca's and André's families, that were identified with low education and income, which can cause problems in the care directed to hospitalized elderly with CVA under palliative care. It is worth mentioning that all families presented conflictual relationships among their members. Therefore, this issue is of great complexity due to the fact that majority of the health professionals, especially nurses, still essentially prac- tise individual care and lack in the care directed to the family.

While using the genogram, it became clearer the portrait of the participant families, since that it was identified similar aspects relevant to their internal structure with multigenerational arrangements, such as, elderly that live with adults, with adolecents and with kids which can lead to conflicts of generations and may complicate the way of caring. With the use of ecomap, it was verified that, as for the external structure, daughters and daughters-in-law mainly composed their supportive care networks.

It is expected that this research can contribute to support new studies in the field of Nursing on the theme "Families of elderly patients with CVA under palliative care", in light of the Calgary Model of Family Assessment. Thus, the difficulty of interviewing other relatives that participate of the systems, in order to expand the view about the experience, stand as a limitation, because the full evaluation of families enables to propose interventions to improve the quality of life of families and help them to glimpse their own solutions to deal with the difficulties with the care of the hospitalized relatives.

This study indicates the need to conduct new researches that aim to further examine the family assessment and, consequently, the use of genogram and ecomap in teaching and clinical practise with the perspective of qualify nursing care.

\section{References}

1. Silva DIS, Silveira DT. Cuidados paliativos: desafio para a gestão e políticas em saúde. Rev Eletr Gestão Saúde. 2015; 6(1):50113. Disponível em: http://gestaoesaude.bce.unb.br/index.php/ gestaoesaude/article/view/1046/pdf

2. Costa FA, Silva DLA, Rocha VM. The neurological state and cognition of patients after a stoke. Rev EsC Enferm USP. 2011;45(5):1083-8.

3. Faria CDCM, Saliba VA, Teixeira-Salmela LF, Nadeau S. Comparação entre indivíduos hemiparéticos com e sem histórico de quedas com base nos componentes da Classificação Internacional de Funcionalidade, Incapacidade e Saúde. Fisioter Pesqui. 2010; 17(3):242-7.

4. Pedreira LC, Lopes RLM. Cuidados domiciliares ao idoso que sofreu Acidente Vascular Cerebral. Rev Bras Enferm. 2010;63(25):837-40. 
5. World Health Organization. Good health adds life to years. Global brief for World Health Day 2012 [Internet]. Geneva; 2012 [acesso em 04 de junho de 2015]. Disponível em: http://www. who.int/ageing/publications/upcoming publications/en/index. $\underline{\mathrm{html}}$

6. Hermes HR, Lamarca ICA. Cuidados paliativos: uma abordagem a partir das categorias profissionais de saúde. Ciênc saúde coletiva. 2013; 18(9): 2577-88.

7. Silva RS, Campos AER, Pereira A. Caring for the patient in the process of dying at the intensive care unit. Rev Esc Enferm USP. 2011;45(3):735-40

8. Wright LM, Leahey M. Enfermeiras e Famílias. Guia para avaliação e intervenções na família. 5 ed. São Paulo: Rocha, 2012.

9. Silva L, Bousso RS, Galera SAF. Aplicação do Modelo Calgary para avaliação de famílias de isodos na prática clínica. Rev bras enferm. 2009; 62(4): 530-4. Disponível em: http://www.scielo. br/scielo.php?pid=S0034-71672009000400006\&script=sci $\underline{\operatorname{arttext}}$

10. Martins MM, Fernandes CS, Gonçalves LHT. A família como foco dos cuidados de enfermagem em meio hospitalar: um programa educativo. Rev bras enferm. 2012; 65(4): 685-90.

11. Academia Nacional de Cuidados Paliativos. Manual de cuidados paliativos. Rio de Janeiro: Diagraphic; p. 320, 2012.

12. Minayo MCS. (org.). Pesquisa social: teoria, método e criatividade. 29 ed. Petrópolis: Vozes, 2010

13. Ministério da Saúde (BR), Conselho Nacional de Saúde. Resolução 466/2012. Brasília: MS; [acesso em 2015 mar 28]. Disponível em: http://conselho.saude.gov.br/resolucoes/2012/ Reso466.pdf.

14. Barbosa, BR, Almeida JM, Barbosa MR, Rossi-Barbosa LAR. Avaliação da capacidade funcional dos idosos e fatores associados à incapacidade. Ciênc saúde coletiva. 2014; 19(8):3317-25

15. Instituto Brasileiro de Geografia e Estatística (IBGE). Censo demográfico 2010: Características da população e do domicílio, resultados do universo (Internet). Rio de Janeiro; 2010 [acesso em 2015 mar 21]. Disponível em: ftp://ftp.ibge.gov.br/Censos/ Censo Demografico 2010/Resultados do Universo/xls/Brasil/ tab1 1 1.zip

16. Tavares DMS, Dias FA, Santos NMF, Haas AJ, Miranzi SCS. Fatores associados com a qualidade de vida de homens idosos. Rev esc enferm USP . 2013; 47(3): 678-85.

17. Alvarenga MRM, Oliveira MAC, Domingues MAR, Amendola F, Faccenda O. Rede de suporte social do idoso atendido por equipes de Saúde da Família. Ciênc saúde coletiva. 2011; 16(5): 2603-11.

18. Serbim AK, Gonçalves AVF, Paskulin LMG. Caracterização sociodemográfica, de saúde e apoio social de idosos usuários de um serviço de emergência. Rev Gaúcha Enferm. 2013 Mar; 34(1): 55-63.

19. Guimarães MBL, Lima CM, Savi EA, Cardoso E, Valla VV, Stotz EN et al. Os impasses da pobreza absoluta: a experiência da Ouvidoria Coletiva na região da Leopoldina, Rio de Janeiro (RJ, Brasil). Ciênc saúde coletiva. 2011; 16(1): 291-300.
20. Lima MG, Barros MBA, César CLG, Goldbaum M c Carandina L, Ciconelli RM. Health related quality of life among the elderly: a population-based study using SF-36 survey. Cad Saude Publica. 2009; 25(10):2159-67.

21. Vera I, Lucchese R, Nakatani AYK, Pagotto $V$, Montefusco SRAI, Sadoyama G. Funcionalidade familiar em longevos residentes em domicílio. Rev Bras Enferm. 2015; 68(1): 68-75.

22. Luz CC, Junger WL, Cavalini LT. Análise da atenção pré-hospitalar ao acidente vascular cerebral e ao infarto agudo do miocárdio na população idosa de Minas Gerais. Rev Assoc Med Bras. 2010; 56(4): 452-7.

23. Burton CR, Fargher E, Plumpton C, Gwerfyl W, Roberts GW, Owen $\mathrm{H}$, et al. Investigating preferences for support with life after stroke: a discrete choice experiment. BMC Health Serv Res. 2014; 14(1) 63-7.

24. Mota FRN, Oliveira ET, Marques MB, Bessa MEP, Leite BMB, Silva MJ. Família e redes sociais de apoio para o atendimento das demandas de saúde do idoso. Esc Anna Nery. 2010; 14 (4):833-8.

25. Reis LA, Torres GV, Xavier TT, Silva RAR, Costa IKF, Mendes FRP. Percepção do suporte familiar em idosos de baixa renda e fatores associados. Texto \& Contexto Enferm 2011; 20:52-8.

26. Santos AL, Cecílio HPM, Teston EF, Marcon SS. Conhecendo a funcionalidade familiar sob a ótica do doente crônico. Texto Contexto Enferm . 2012;21(4):879-86.

27. Machado ALG, Jorge MSB, Freitas CHA. A vivência do cuidador familiar de vítima de Acidente Vascular Encefálico: uma abordagem interacionista. Rev Bras Enferm. 2009; 62(2): 24651.

28. Pereira RA, Santos EB, Fhon JRS, Marques S, Rodrigues RAP. Sobrecarga dos cuidadores de idosos com acidente vascular cerebral. Rev esc enferm USP. 2013; 47(1): 185-92.

29. Gratão ACM, Talmelli LFS, Figueiredo LC, Rosset I, Freitas CP, Rodrigues RAP. Dependência funcional de idosos e a sobrecarga do cuidador. Rev esc enferm USP. 2013; 47(1): 137-44.

30. Seima MD, Lenardt MH, Caldas CP. Relação no cuidado entre o cuidador familiar e o idoso com Alzheimer. Rev bras enferm. 2014; 67(2): 233-40.

\section{Publish in International Archives of Medicine}

International Archives of Medicine is an open access journal publishing articles encompassing all aspects of medical science and clinical practice. IAM is considered a megajournal with independent sections on all areas of medicine. IAM is a really international journal with authors and board members from all around the world. The journal is widely indexed and classified Q1 in category Medicine. 